\title{
Why are There Fewer Marsupials than Placentals? On the Relevance of Geography and Physiology to Evolutionary Patterns of Mammalian Diversity and Disparity
}

\author{
Sánchez-Villagra, Marcelo R
}

DOI: https://doi.org/10.1007/s10914-012-9220-3

Posted at the Zurich Open Repository and Archive, University of Zurich ZORA URL: https://doi.org/10.5167/uzh-71489

Journal Article

Published Version

Originally published at:

Sánchez-Villagra, Marcelo R (2013). Why are There Fewer Marsupials than Placentals? On the Relevance of Geography and Physiology to Evolutionary Patterns of Mammalian Diversity and Disparity. Journal of Mammalian Evolution, 20(4):279-290.

DOI: https://doi.org/10.1007/s10914-012-9220-3 


\title{
Why are There Fewer Marsupials than Placentals? On the Relevance of Geography and Physiology to Evolutionary Patterns of Mammalian Diversity and Disparity
}

\author{
Marcelo R. Sánchez-Villagra
}

Published online: 22 December 2012

(C) Springer Science+Business Media New York 2012

\begin{abstract}
Placental mammals occupy a larger morphospace and are taxonomically more diverse than marsupials by an order of magnitude, as shown by quantitative and phylogenetic studies of several character complexes and clades. Many have suggested that life history acts as a constraint on the evolution of marsupial morphology. However, the frequent circumvention of constraints suggests that the pattern of morphospace occupation in marsupials is more a reflection of lack of ecological opportunity than one of biases in the production of variants during development. Features of marsupial physiology are a potential source of biases in the evolution of the group; these could be coupled with past macroevolutionary patterns that followed conditions imposed by global temperature changes. This is evident at the K/Pg boundary and at the Eocene/Oligocene boundary. The geographic pattern of taxonomic and morphological diversity in placental clades mirrors that of extant placentals as a whole versus marsupials: placentals of northern origin are more diverse those of southern one and include the clades that are outliers in taxonomic (rodents and bats) and ecomorphological (whales and bats) richness.
\end{abstract}

Keywords Evolution · Extinction · Paleontology · Phylogeny $\cdot$ Development $\cdot$ Constraint $\cdot$ Limbs

...the interpretation that life-history changes are correlated with certain early embryogenic events is, although appealing, very problematic. It should be

M. R. Sánchez-Villagra ( $\bowtie)$

Paläontologisches Institut und Museum, Universität Zürich,

Karl Schmid-Strasse 4,

CH-8006, Zürich, Switzerland

e-mail:m.sanchez@pim.uzh.ch considered that selection can act at any point during ontogenesis, and also that the degrees of freedom in evolutionary changes to development are very high. Mitgutsch et al. (2009: 255)

...universal (and local) constraints need not to be inevitable. They may be accidents of evolutionary history...

A. Wagner (2011: 158)

In a world of chance, is there a better and worse?

Foe, by J. M. Coetzee (1986: 30)

\section{Introduction}

Mammals are a well-known major group of organisms, with much documented about their fossil record, developmental biology and ecology, and as such a good subject to explore the fundamental question of biology of why the number of species varies among groups (Wiens 2011). Marsupials and placentals constitute the two major groups of living mammals and present a natural experiment in evolution. We can learn much by examining and comparing the course of evolutionary change in the two lineages in the last 160 million years (Luo et al. 2011), integrating information on external and internal factors that affected both. Marsupials, of which there are about 340 species, are largely confined geographically to Australia and South America, besides a few opossum species (didelphids) distributed in Central and North America. Placentals have a worldwide distribution on land and in the seas and are much more diverse, with 5138 species (Wilson and Reeder 2005; 
Dickman 2007; Ceballos and Ehrlich 2009; Voss and Jansa 2009). The evolutionary success of placentals seems tremendous when compared with their sister group the marsupials or with egg-lying mammals, the monotremes (Lillegraven et al. 1987; Sears 2004; Cooper and Steppan 2010).

There is a nomenclatural distinction between stem and crown groups that is informative and relevant when treating mammals. Metatherians are all mammals phylogenetically closer to an extant opossum or kangaroo than to a mouse or elephant, and marsupials, which form the crown group, are all the descendants of the last common ancestor of extant marsupials. Similarly, the more inclusive Eutheria contain the crown group Placentalia (Rougier et al. 1998).

Concerning ecomorphological diversity, the convergences of marsupials with placentals are textbook knowledge (Pough et al. 2008) and include the marsupial mole, anteater (numbat), wolf, among other forms (Jones 2003; Wroe and Milne 2007). The fossil record in spite of its incompleteness does document a substantial addition in our understanding of metatherian ecomorphological diversity, with for example a 2.7 ton marsupial "rhino" Diprotodon (Wroe et al. 2004b), the frugivorous Paleogene polydolopimorphians with multi-cuspid molars (Goin et al. 2012), and the distantly related diprotodontian (thylacoleoinid) and borhyaenid hypercarnivores of Australia and South America, respectively (Wroe et al. 2003; Forasiepi and Carlini 2010). The recently extinct bandicoot Chaeropus had feet similar to those of a pig, with hoof-like structures (Gordon and Hulbert 1989). But these examples pale in comparison with the figures and disparity reached by placentals. Limb specializations such as wings and flippers never evolved among marsupials. Even excluding whales, the range of body sizes of placentals is also more extensive; the fossil rhinocerontid Paraceratherium reached a maximal body mass of about 15-20 tons (Fortelius and Kappelmann 1993). In the lowest extremes (few grams) the figures for metatherians and eutherians are similar, although the record of the smallest mammal known is that of a eutherian (Bloch et al. 1998).

In the late 1970 s and the 1980 s a series of papers discussed the marsupial/placental dichotomy, emphasizing their contrasting reproductive and developmental biology (Lillegraven 1975; Kirsch 1977; Lillegraven et al. 1987). Gestation length in marsupials is quite variable, ranging from about 11 to 38 days, but this is barely reflected in the degree of development at birth, as all marsupial neonates are generally altricial, but some aspects of their anatomy are much more differentiated than others (Hughes and Hall 1988). In marsupials the newborn needs to be able to feed at an early stage of morphogenesis when compared with placentals, and in most species, presumably the primitive condition, the newborn needs to use its forelimbs to climb and reach the mother's teats (Gemmel et al. 2002; Sears
2004). A lack of "feto-maternal intimacy" (Lillegraven 1975:714) and the needs imposed by the newborn's locomotion and subsequent suckling during a period of fixation are unique and most likely derived features of marsupials among living mammals (Smith 2001a; Weisbecker 2011). Although marsupials do develop with protection and assistance of a placenta, the mechanisms involved in marsupials are fundamentally different from the those of members of Placentalia, and do not provide a comparable level of protection from the mother's immune system (Renfree 1993; Tyndale-Biscoe 2005).

As the subject of constraints in evolution gained centerstage (Gould 1977), the differential evolutionary paths of marsupials and placentals began to be discussed in the context of how marsupials' developmental features must have played a role in their lower taxic and morphological diversification (Werdelin 1987). Others raised voices and presented data on the seemingly underappreciated marsupial diversity in taxonomy and morphological disparity (Kirsch 1977), but discussions remained anecdotal and data quantification missing.

During the last three decades, major advances have been made in our knowledge of mammalian biology and evolution. This has involved quantification of ontogenetic and adult morphospace data (Sears 2004) and a much more solid knowledge about phylogeny, the fossil record, and macroevolutionary patterns of marsupials (Rougier et al. 1998; Luo et al. 2003; Goin et al. 2010; Beck 2012) and placentals (Rose 2006; Meredith et al. 2011). We also now have an unprecedented understanding of the metabolic, physiological, and reproductive differences between marsupials and placentals (Renfree 1993; Tyndale-Biscoe 2005; McNab 2008). In addition, conceptual advances have been made, such as the study of modularity and sequence heterochrony, relevant to understanding the developmental and evolutionary differences between the two groups (Smith 2001a; Goswami et al. 2009). Reconsidering the marsupial dichotomy is thus timely. For that, some of the major discoveries are summarized and a discussion of the potential geographical and physiological factors that may have played a role in the differing fates of the two major groups of mammals is presented.

\section{Adult Morphospace and Quantitative Comparative Ontogeny}

In the scapula (Sears 2004), limbs (Cooper and Steppan 2010; Kelly and Sears 2011a), and axial skeleton (Sánchez-Villagra et al. 2007), placentals show more disparity than marsupials. For example, all marsupials, independent of the locomotory type and phylogenetic position, possess 19 thoracolumbar vertebrae (and low intraspecific variability), a number which ranges from 15 to 32 in 
placentals (Asher et al. 2011). With the exception of the marsupial mole Notoryctes, marsupials have less specialized forelimbs than placentals (Kelly and Sears 2011a) and tend to specialize their hind limbs more than their forelimbs, as seen very clearly in kangaroos. Several limb features associated with cursoriality found in terrestrial placentals, such as those of ungulates and some South American rodents, are not found among the marsupials (Cooper and Steppan 2010). The different pattern of adult limb morphospace occupation in marsupials versus placentals was related by all the above-cited authors to the contrasting pattern of development and the hypothesized associated constraints in marsupials. In contrast, a recent study concentrating on the skull came to a different conclusion. Goswami et al. (2011) quantified three measures of cranial disparity, using geometric morphometric methods, in a comprehensive sample of eutherian and metatherian carnivoran species. They concluded that "contrary to previous studies, metatherian carnivores consistently exhibited disparity which exceeded that of the much more speciose eutherian carnivore radiations, refuting the hypothesis that developmental constraints have limited the morphological evolution of the marsupial cranium" (p. 1831).

Differences in timing of ontogenetic events between marsupials and placentals exist in early embryogenesis. These involve somitogenesis, neural tube closure, cranial neural crest migration, and forelimb specification and patterning (Vaglia and Smith 2003; Sears 2009; Keyte and Smith 2010, 2012). In Monodelphis domestica neural tube closure takes place after development of somites, whereas it precedes it in Mus and Rattus (Vaglia and Smith 2003). Another difference is that cranial neural crest among marsupials develops relatively early compared to event sequences among placentals (Smith 2001b).

In comparing marsupials and placentals, the contrast between forelimbs and hind limbs has been central. The primitive and common condition of vertebrates is earlier development of the forelimb/pectoral fin than of the hind limb/pelvic fin (Richardson et al. 2009). This is taken to a unique extreme in marsupials, as quantified in different aspects of chondrogenesis (Bininda-Emonds et al. 2007). Not all aspects of skeletogenesis (pre-chondrification, chondrification, onset of ossification, growth) occur at similar relative timings. A decoupling of the timing of these processes has been shown (Hamrick 1999; Sears 2009). Marsupials exhibit an acceleration of the forelimb appearance and a subsequent retardation of the hind limb development.

In both the postcranium (Weisbecker et al. 2008) and skull (Sánchez-Villagra et al. 2008; Hautier et al. 2010), marsupials and placentals differ in the sequence of bone ossifications. For example, marsupials show a clear antero-posterior gradient of ossification throughout the skeleton and their oral region ossifies first. Placentals, in contrast, exhibit a less marked antero-posterior temporal gradient of ossification sequence, for example with the parietal bone of the skull roof ossifying relatively early (Sánchez-Villagra et al. 2008).

The diversity of dental features in placentals seems to be larger (Ungar 2010), also at the microstructural level (Koenigswald and Goin 2000), but the fossil record provides excellent examples of unsuspected dental disparity across Metatheria (Arena et al. 2012). The pattern of dental replacement is also contrasting. Many marsupial clades retain two developmental generations of teeth, but always one of them is reduced and vestigial, so a single functional generation exists except for the replacement in the last premolar locus (Luckett 1993), even in the basal lineages of extinct metatherians (Cifelli and Muizon 1998; see Archer 1978 and references therein for an alternative identity interpretation of marsupial teeth). In contrast, placentals have a much broader range of dental replacement patterns, including the primitive condition of replacement of most non-molars, the loss of functional replacement in different loci in different combinations, and even the marsupial condition (van Nievelt and Smith 2005). It has been argued that the reduced tooth replacement has resulted in a negative bias in dental morphospace (restricted generation of variation) among carnivorous marsupials (Werdelin 1987; Prevosti et al. 2012). However, circumventions of such a constraint are known: the "marsupial lions" (Thylacoleonidae; late Oligocene-Pleistocene, Australia; Archer et al. 2001) reduced their molars and used their premolars as carnassials (Werdelin 1988); the Mio-Pliocene saber tooth marsupials (Thylacosmilidae) had ever growing upper canines and blade-like molars (e.g., Forasiepi and Carlini 2010); and adult "giant rat-kangaroos" (Propleopinae) from the Oligocene-Miocene of Australia (Wroe et al. 1998; Goswami et al. 2011) used the only tooth which is replaced, the last premolar, as the principal vertical shearing blade. In juvenile propleopines the principle carnassial tooth is the $\mathrm{P} 2 / 2$, which worked in conjunction with the adjunct blade of the trigonid of the $\mathrm{dP} / 3$ in the lower dentition (Wroe and Archer 1995).

\section{Brain Size and Physiology}

Weisbecker and Goswami (2010) discussed and analyzed comprehensive data that serve to reject the idea that marsupials are smaller-brained than placentals (e.g., Lillegraven 2003; Burghardt 2005). These authors also presented quantitative evidence that there is a lack of correlation between metabolic turnover and marsupial brain size. These two variables had been hypothesized to be tightly coupled based on the study of placental mammals alone (Isler and van Schaik 2009). This difference may be related to the fact that marsupial life history involves a long period of lactation 
instead of intrauterine life. The maternal care provides an environment in which seemingly extended brain growth is possible under relatively small metabolic budgets.

There are fundamental physiological differences between placentals and marsupials. Among placentals, a higher metabolic rate is correlated with higher rate of reproduction. In marsupials, such correlation does not exist given their small investment in prenatal development (McNab 2005). The extreme aerobic/metabolic features of kangaroos (Dawson et al. 2004) and the hibernation capabilities of the pygmy possum Burramys parvus (Geiser 1994) are among the best examples of the evolvability of marsupials in physiological terms. Comprehensive studies of physiological patterns and their potential effects on placentals versus marsupial macroevolution would be important.

Placentals can generate heat using Brown Adipose Tissue (BAT) (Cannon and Nedergaard 2004), either lacking in marsupials (Hayward and Lisson 1992; Geiser 1994) or not used for heat generation as it is in placentals (Hope et al. 1997; Jastroch et al. 2008). Placentals are thus better suited to avoid hypothermia, and have higher metabolic rates relative to marsupials of similar weight (Tyndale-Biscoe 2005). This helps placentals to survive cold temperatures (McNab 2008). Marsupial heat generation derives from metabolism and muscular activity (Holloway and Geiser 2001). Given the physiological features of marsupials, food availability plays a particular major influence on the fate of their populations, and marsupial distribution in high latitudes is restricted in extent and number of species (Formoso et al. 2011). The highest latitude/southernmost record for marsupials is $47^{\circ} \mathrm{S}$, for Lestodelphys halli (Formoso et al. 2011), and only four marsupial species are known to occur south of $42^{\circ} \mathrm{S}$ (Martin et al. 2008). As food availability is largely determined by temperature and rainfall, these variables are likely to then be ultimately coupled with marsupial evolution, more so than in placentals. This is in fact the case found when examining macroevolutionary patterns of metatherian evolution (Goin et al. 2010).

\section{Time of Divergence and Diversity Patterns in Geological Time and Space}

The evolutionary lines of metatherians and eutherians are, by definition, equally old, with a divergence in the Jurassic (Luo et al. 2011; dos Reis et al. 2012). But within these two lineages, the age of the living clades are not. The origin of the crown marsupials occurred later than that of crown placentals by at least around 20 million years (Nilsson et al. 2004; Bininda-Emonds et al. 2007; Beck 2008; Meredith et al. 2008, 2011), as did on average the radiation of marsupial in comparison to placental "orders" (Meredith et al. 2011). It was previously thought that the clade of living Marsupialia originated in the Cretaceous (Novacek 1992), and that some modern lineages (e.g., Didelphidae) represented "living fossils" (Simpson 1980). However, new fossils and comprehensive phylogenetic analyses of the relevant fossil forms (Rougier et al. 1998; Luo et al. 2003; Sánchez-Villagra et al. 2007; Horovitz et al. 2009; Vullo et al. 2009; but see Beck 2012) have shown that the Cretaceous forms are stemmetatherians and that crown marsupials are exclusively from the Cenozoic. In other words, stem metatherians have a long history within the Mesozoic. Marsupials, in contrast, are much younger.

In the Late Cretaceous, metatherians were very important components of North American mammalian faunas in both diversity and abundance, surpassing their contemporaneous and sympatric eutherians (Wilson et al. 2010; Archibald 2011). The ecomorphological diversity of metatherians included a large animal by Mesozoic standards (Nanocuris) of about $0.5 \mathrm{Kg}$ of body mass, and a semi-aquatic eater of hard-shelled organisms (but see Fox and Naylor 2006 for an alternative habitat reconstruction), Didelphodon vorax with about 1.7 Kg (Luo 2007; Wilson et al. 2010; G. P. Wilson pers. comm.). The Cretaceous/Paleogene boundary (K/Pg) was a critical time for marsupial biogeography and evolution. The catastrophic event at the end of the Cretaceous, possibly related to an asteroid impact in southern North America (Yucatán Peninsula; Schulte et al. 2010, but see Archibald 2011), had a strong effect on metatherians, which experienced a precipitous decline in diversity (J. Alroy, in Archibald 2011:65). In North America the K/Pg changes were much more dramatic in metatherians than in eutherians or multituberculates: one of 11 metatherians survived, whereas five out of ten multituberculates did, and the majority of eutherians also survived, as documented at the Hell Creek Formation in northeastern Montana (Wilson 2005; Archibald 2011). Factors such as sleep- or hide behavior, which allows mammals to buffer from changing physical elements and makes them less prone to extinction (Liow et al. 2009), may have varied between mammalian clades at the end of the Cretaceous period. Another potential factor for differential survivorship might have been differential ability to thermoregulate (for example, the lack in metatherians of brown adipose tissue).

After the critical extinction event at the end of the Cretaceous, metatherians were almost entirely restricted to the southern hemisphere, except for a few dentally plesiomorphic tribosphenic metatherians that inhabited northern continents and Africa until mid-Cenozoic times (Hooker et al. 2008). In addition, and much later, some didelphids migrated to North America during the Great American Biotic Interchange at about $3 \mathrm{Ma}$, following the formation of the Panamanian land bridge (Woodburne 2010).

There are no uncontested reports of Mesozoic metatherians in either South America or Australia (Rougier et al. 2011). Thus it is likely that in the Late Cretaceous or Paleocene 
metatherians dispersed from North to South America and then Australasia (Case et al. 2004; Beck 2012; Black et al. 2012). Supporting this idea are metatherians known from the middle Eocene of Antarctica (Woodburne and Zinsmeister 1982; Goin et al. 1999; Chornogubsky et al. 2009). By latest Paleocene-early Eocene times, the diversity of metatherians in South America was large, as extensively documented by one the world's most diverse assemblages of this group (besides Riversleigh, see Archer et al. 2001), surpassing living ones (Muizon 1991; Oliveira and Goin 2006; Goin et al. 2012). This diversity included forms without extant counterparts such as the frugivorous polydolopids and the herbivorous groeberiids. In one of the best studied Paleocene localities of South America, Tiupampa in Bolivia, more than half of the mammalian species are metatherians (Muizon and Céspedes 2012). This percentage ranges between 60 and $70 \%$ and approaches the proportion suggested for other wellstudied localities between the late Paleocene and the middle Eocene: Itaboraí in Brazil and Las Flores and Paso del Sapo in Argentina (Bergqvist et al. 2006; Tejedor et al. 2009).

The Earth experienced greenhouse conditions from the Late Cretaceous until the Eocene-Oligocene boundary (Zachos et al. 2001). The "Terminal Eocene Event" of major changes in global temperatures also affected South America, and significant faunal changes are well documented at the EoceneOligocene boundary in Patagonia, the "Bisagra Patagónica" or "Patagonian Hinge" (Goin et al. 2010). Around middle Eocene times, hystricognath rodents arrived in South America (41 Ma; Antoine et al. 2012). Primates did so in the late Oligocene if not before, around 26-28 Ma (Kay et al. 1998). Goin et al. (2010) argued that the most dramatic change in the diversity of marsupials relative to placentals in South America occurred not as result of the arrival of these new clades, but due to climate change. The immigrant groups (hystricognaths and primates) are absent from the early Oligocene sites in which the metatherians represented only $30 \%$ of the mammals (Goin et al. 2010). This decline in the proportion of marsupials in mammalian faunas becomes even more marked towards the second half of the Cenozoic.

\section{No Competitive Replacement of Marsupials by Placentals}

Replacement of marsupials by placentals has been suggested for several times and places, implying a role for competition in mammalian macroevolutionary patterns. According to this view (Patterson and Pascual 1972; Simpson 1980; Lillegraven et al. 1987; Werdelin 1987), marsupials are diverse in Australia because non-volant placentals (probably) never fully established themselves there, and whenever the two groups have been in contact, placentals have prevailed. In this context, it would be fortunate if consensus would be reached on the affinities of Tingamarra, a purported "condylarth" (eutherian) from the early Eocene of Australia (Godthelp et al. 1992; but see Woodburne and Case 1996, for an alternative interpretation). From the same locality from which Tingamarra has been described, one of the oldest bats, Australonycteris clarkae, is known (Hand et al. 1994). Future work may demonstrate that in Australia the marsupials had the upper hand over placentals since Paleogene times.

Proving competition in recent species, let alone fossils, is a challenging task (Benton 2009). In the case of marsupials and placentals, only one study made a systematic and quantitative examination of potential competitive replacement and concerned the carnivore guild in South America around the time of the great American biotic interchange (Prevosti et al. 2011).

The Sparassodonta was a diverse group of carnivorous metatherian forms $(\approx 1-50 \mathrm{~kg})$ that together with "terror" birds (Phorusrhacidae), terrestrial crocodiles (Sebecidae), and large snakes (Madtsoiidae) occupied the carnivore adaptive zone during most of the Cenozoic in South America (Marshall 2004). The diversity of Sparassodonta decreased towards the late Miocene and the group became extinct in the Pliocene about $3 \mathrm{Ma}$. The first appearance of (placental) carnivorans to South America (about 6-7 Ma) has been suggested as the cause of this decline and extinction (e.g., Patterson and Pascual 1972; Simpson 1980; Werdelin 1987). A recent analysis summarizing diversity, estimations of size and diet, and first and last appearances contradicts this view, as there was apparently no temporal coexistence between the assumed carnivorous ecological counterparts (Prevosti et al. 2011). The Carnivora occupied new adaptive space by opportunistically replacing, rather than outcompeting, the sparassodonts.

\section{Placental Ordinal Diversity and Biogeographic Patterns Mirrors the Placental/Marsupial Pattern}

The phylogeny of living placentals shows a pattern of geographic distribution that correlates to taxonomic and morphological diversity in a manner similar to the pattern of the marsupial/placental dichotomy (Fig. 1). The most diverse placental groups are northern ones, building the Boreoeutheria (5,010 spp.), not the southern ones, which may build a monophyletic Atlantogenata (128 spp.). The geographic division of the placental clades is not simple when we consider the fossil record (Zack et al. 2005), and the current distributions of living clades does not correspond exactly to the places of origin. But the correlation of geographic area to speciation is evident.

The northern continents occupy much more terrestrial surface than southern continents (excluding Antarctica), 78.5 million $\mathrm{km}^{2}$ and 57.2 million $\mathrm{km}^{2}$, respectively, and it 
Fig. 1 Summary of main patterns and events discussed in the text. Sketches and diversity not to scale. Times of divergence are averages taken from the ranges reported in dos Reis et al. (2012) and in the case of ordinal divergences within Marsupialia, from Meredith et al. (2011). Number of extant species in the four major clades of placental mammals and marsupials based on Wilson and Reeder (2005), with additions from Ceballos and Ehrlich (2009) and Voss and Jansa (2009) representation of taxonomic

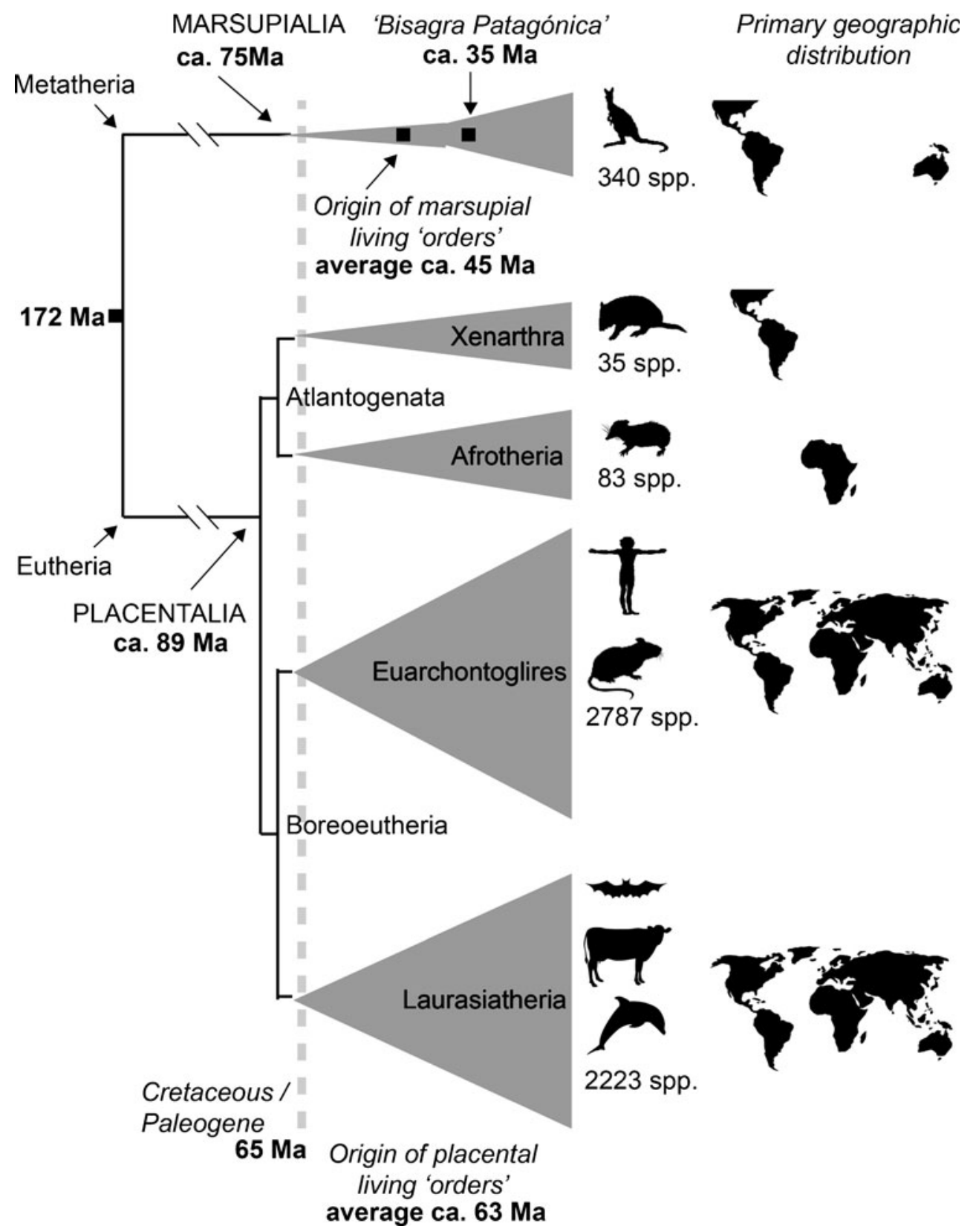

MARSUPIALIA 'Bisagra Patagónica’

ca. $75 \mathrm{Ma}$
$83 \mathrm{spp}$.

2787 spp.

2223 spp. is in the northern continents where current fossil evidence suggests the most diverse placental "orders" originated and are primarily distributed. Whatever conditions prevailed that facilitated or "made possible" the evolution of bats, this happened in the northern continents among the Boreoeutheria, not in the southern ones among the Atlantogenata. For all the convergences demonstrated between atlantogenatans and boreoeutherians (Springer et al. 2004), there are no atlantogenatans that have converged on bats. The same is true for cetaceans, although the marine realm is a special case as stem whales are originally recorded from the Southern portion of the globe, which has a greater cover by water. The greatest radiation of rodents, the taxonomically most diverse group, also occurred predominantly in the northern continents. The almost complete restriction of marsupials to South America and Australia in the Cenozoic is well established. Africa, a continent in which living marsupials are absent, has been a stage of much of the diversification of boreoeutherian clades. The few and poorly known fossil metatherians from the Paleogene of the northern part of Africa are most likely related to European forms (Hooker et al. 2008). The large area of Asia may be the basic reason why this continent has been the place of origin of many groups of mammals (Beard 2002).

The relation of area to speciation is not simple, given the many factors involved (Parent and Crespi 2006). But in general, the larger the geographic area, the higher the rate of speciation, as shown by both models and empirical data 
(Gavrilets and Losos 2009). This relation has played a major role in mammalian evolution (Wroe et al. 2004a).

\section{Circumvention of Constraints and Plasticity of Development}

Decades of studies at the molecular and organismal level have revealed not only the pervasive role of developmental biases in the generation of variation upon which natural selection operates (Arthur 2011), but also the circumventing of such biases under special ecological opportunities (Losos 2010). Giraffes and talpid moles, two groups of boreoeutherian placentals, provide examples of this.

The elongation of the giraffe neck is a good example of the circumvention of a "constraint" given functional demands. If the genetic programme of development is "fixed" at seven cervicals, notwithstanding the deviations in sloths, manatees, and dugongs (Hautier et al. 2010), and if selection operates in favor of a longer neck, then elongation of the individual elements is the option. Similarly, the pentadactyl constraint is universal in crown tetrapods, but talpid moles have found a way around it, as have panda bears (Gould 1980). In moles this occurred with the migration of a carpal element into the digital area with minimal modifications in the expression pattern and timing of important molecules involved in limb development so far investigated (Mitgutsch et al. 2012). Different but also relevant examples of plasticity in development are known within species (Moczek et al. 2011), as in the case of limb length changes in Anolis sagrei raised on different kinds of surfaces (Losos 2010).

If the perinatal biology of marsupials has not actually been the key factor preventing members of this group from evolving wings, how would we know it? While the observation that there are no winged marsupials is compelling, it is not sufficient to demonstrate this negative conclusion. In fact, empirical data show that compared to placentals, forelimbs in marsupials are actually less integrated as a module with hind limbs (Bennett and Goswami 2011; Kelly and Sears 2011b). This would seemingly make a functionally volant or aquatic transformation more likely, not less. In any event, the relation of modularity to morphological evolution is far from established. Furthermore, the typically marsupial climb to reach mother's teats at birth might be possible with an early stage of a developing wing. Even well-developed forelimb-wings are terrestrially competent, as demonstrated by Mystacina tuberculata, (New Zealand's lesser short-tailed bat), and occasionally by the vampire bat Desmodus rotundus (Hand et al. 2009).

Other fundamental insights have been gained when considering the modularity among different aspects of development or time windows of ontogeny. An example is the independence of chondrogenesis from ossification timing (Fröbisch 2008). Another example is the timing of development of the cranial neural crest, neural tube differentiation, and somite formation in discoglossid frogs by Mitgutsch et al. (2009:255). According to these authors, they “....could not identify any obvious relation of our embryonic data with peculiarities of post-embryonic stages. Cell populations contributing to head mesenchyme interplay in a highly integrated yet developmentally plastic manner."

In the case of limb evolution, bat wings provide an example of how the developmental penetrance (Richardson 1999) of an adult character can be limited even in the case of a derived morphology. Digits in bats are initially close in size to those of mice, and subsequent lengthening results in the wing proportions (Sears et al. 2006). Changes in the differentiation of digit elements and in the regulation of their longitudinal growth are accomplished via an increase in Bmp2 expression and Bmp signalling in bat forelimbs in relation to hind limbs. Morphological innovations can result from just a few key developmental genetic changes. These discoveries further support the biological possibility of wings in marsupials speculated above, because of the "simplicity" of the mechanism of wing development and its limited impact on early aspects of skeletogenesis.

\section{Conclusions and Outlook}

In comparison with marsupials, placentals occupy more morphospace and have higher species diversity. This pattern is predominant when we consider the fossil record, but there are exceptions, such as the comparable, if not larger, ecomorphological and taxonomic diversity of metatherians versus eutherians in the Late Cretaceous of North America and in the Paleogene of South America.

The marsupials' limited diversification and disparity seems consistent with a constraint hypothesis, in which their reproductive biology involving early birth and extra-uterine organogenesis places requirements that negatively bias the morphological diversification of the group. However, there are no simple correlates between morphological features of marsupials (or lack thereof) and reproductive biology. For example, the suppression of dental replacement cannot be explained as a direct result of nipple attachment after birth, as this suppression is not a unique feature of marsupials (Van Nievelt and Smith 2005). Marsupial heterochronies in early organogenesis have been tied to the different reproductive and later ontogenetic differences around birth time between marsupials and placentals (Vaglia and Smith 2003). These coupling of events exist, but case studies point out the potential flexibility of such timings and processes.

The great plasticity in development and the importance of modularity suggest that (1) under proper suitable conditions, if developmental biases exist, they can be circumvented, and (2) events in early organogenesis do not necessarily determine the fate of adult morphological structures. Some events have a 
deep developmental penetrance; others do not (Bickelmann et al. 2012).

A key aspect of the marsupial-placental dichotomy to address is the distribution in time and space of the two groups throughout their entire evolutionary histories. Metatherians were acutely affected at the $\mathrm{K} / \mathrm{Pg}$ boundary (Wilson et al. 2012), after which they were restricted geographically, largely to the southern hemisphere. Crown marsupials are a younger clade than crown placentals (Meredith et al. 2011; dos Reis et al. 2012), and the radiation of living marsupials orders occurred about 20 my later than that of living placentals (Meredith et al. 2011). Crown marsupials radiated exclusively in South America, Antarctica, and Australia. South American metatherians radiated widely in the presence of eutherians, which included "condylarths" and "meridiungulates" during the early Cenozoic.

There were metatherians on northern continents during the Cenozoic -herpetotheriids and peradectids - and they were far less diverse than those on southern continents. But this does not contradict the geographic argument presented in this paper. After the differential extinction at the end of the Cretaceous discussed above, the evolutionary race of the two therian clades in the northern continents did not start equal. In the early Paleogene the metatherians were already decimated. Why didn't herpetotheriids and peradectids ever become as diverse as their southern relatives, despite being on larger landmasses? There have been no studies of potential competitive exclusion of these metatherians by Cenozoic eutherians. Even if competitive exclusion happened, this fact would not contradict the major tenant of this paper. Relict, once flourishing groups have persisted in some land masses until becoming extinct. Examples are the remnants of non-therian lineages (Peligrotherium, gondwanatherians, Monotrematum, Necrolestes; Phillips et al. 2009; Rougier et al. 2012) that persisted into the early Cenozoic of South America (Pascual et al. 1992). Paleogene metatherians in North America are an example of such a pattern.

Most importantly, the overall pattern of diversity and disparity between "northern" and "southern" placental clades mirrors that between marsupials and placentals. This further supports the decisive role that geography must have played in mammalian evolution.

To understand the dynamics of the marsupial-placental dichotomy, the following question becomes paramount: what demographic, ecological, or physiological factors propelled the differential survival or diversifications of marsupials and placentals at critical times of earth history, such as the K/Pg or the Eocene/Oligocene boundaries? The investigation of faunal dynamics and life history evolution (Maridet and Costeur 2010) at these critical times is important. Also relevant are quantitative studies of morphospace occupation by marsupials versus placentals across geological time.

Rates of speciation and extinction and the amount of time in a region are responsible for species richness. All these factors could be studied quantitatively to compare mammalian clades. Analytical approaches that incorporate stratigraphical information into molecular data analyses are being developed (Rabosky and Alfaro 2010), and some models incorporate geographic parameters (Pigot et al. 2010).

The last 30 years have seen great advances in our understanding of the placental-marsupial dichotomy. At this pace, the solutions to the questions that seem unanswerable today will be in much better footing in years to come. For example, studies of the genome and of early embryogenesis and placentation should be able to provide a better understanding of the reproductive physiology and the origin of viviparity in therians (Lynch et al. 2008; Frankenberg et al. 2011; Meslin et al. 2012; Sumiyama et al. 2012). Studies of the genome may reveal information on evolvability and on the timing and mode of developmental innovations (Wagner 2011).

The quantification of ontogeny in a phylogenetic framework (Smith 2001a; Sears 2004; Weisbecker et al. 2008; Wilson and Sánchez-Villagra 2010; Bennett and Goswami 2011; Koyabu et al. 2011; Goswami et al. 2012) has brought rigor to the studies of developmental biases (Arthur 2011) in mammalian evolution, and the increased knowledge of phylogeny and timing of origin of groups (Meredith et al. 2011; Goswami 2012; dos Reis et al. 2012) provides a solid framework in which to study them. "Constraint" should refer to a specific trait, not to a whole organism. The relation of a constraint for a particular character complex and the evolutionary dynamics of the organisms are probably far from simple. Many factors are involved in ecological opportunity and the resulting niches occupied by marsupial and placental mammals. Geography and its associated biotic components, might simultaneously be the most important and least appreciated.

Acknowledgments I thank D. Koyabu and T.M. Scheyer for multiple help, G.P. Wilson for providing body mass data, and R.J. Asher, A.M. Forasiepi, W. Salzburger, and L.A.B. Wilson for thoughtful reviews of previous drafts. M. Archer and R.M.D. Beck provided very constructive and insightful reviews. I thank the Swiss SNF (Grant No. 31003A-133032/1) for financial support. I also thank A. Goswami, V. Weisbecker, I. Horovitz, F.J. Goin, W. Maier, and R.J. Asher for several fruitful years of collaborations examining the marsupial/placental dichotomy and other colleagues including L. Werdelin, S. Wroe, K.E. Sears, and my mentor K.K. Smith for bringing empirical data and rigor to the study of constraint in mammalian clades. I dedicate this essay to the memory of J.A.W. Kirsch.

\section{References}

Antoine PO, Marivaux L, Croft DA, Billet G, Ganerød M, Jaramillo C, Martin T, Orliac MJ, Tejada J, Altamirano AJ, Duranthon F, Fanjat G, Rousse S, Gismondi RS (2012) Middle Eocene rodents from Peruvian Amazonia reveal the pattern and timing of caviomorph origins and biogeography. Proc Roy Soc B 279:1319-1326 
Archer M (1978) The nature of the molar-premolar boundary in marsupials and a reinterpretation of the homology of marsupial cheekteeth. Mem Queensland Museum 18:157-164

Archer M, Hand S, Godthelp H (2001) Australia's Lost World: Prehistoric Animals of Riversleigh. Indiana University Press, Bloomington

Archibald JD (2011) Extinction and Radiation: How the Fall of the Dinosaurs Led to the Rise of The Mammals. Johns Hopkins University Press, Baltimore

Arena DA, M Archer, H Godthelp, SJ Hand, S Hocknull (2012) Hammer-toothed 'marsupial skinks' from the Australian Cenozoic. Proc Roy Soc B 278: 3529-3533

Arthur W (2011) Evolution. Wiley-Blackwell, Chichester

Asher RJ, Lin KH, Kardjilov N, Hautier LJ (2011) Variability and constraint in the mammalian vertebral column. J Evol Biol 24:1080-1090

Beard C (2002) East of Eden at the Paleocene/Eocene Boundary. Science 295:2028-2029

Beck RMD (2008) A dated phylogeny of marsupials using a molecular supermatrix and multiple fossil constraints. J Mammal 89:75-189

Beck RMD (2012) An 'ameridelphian' marsupial from the early Eocene of Australia supports a complex model of Southern Hemisphere marsupial biogeography. Naturwissenschaften 99:715-729

Bennett CV, Goswami A (2011) Does reproductive strategy drive limb integration in marsupials and monotremes? Mammal Biol 76:79-83

Benton MJ (2009) The Red Queen and the Court Jester: species diversity and the role of biotic and abiotic factors through time. Science 323:728-32.

Bergqvist LP, Lima Moreira A, Ribeiro Pinto D (2006) Bacia de São José de Itaboraí. 75 Anos de História e Ciência. Serviço Geológico do Brasil, Rio de Janeiro

Bickelmann C, Mitgutsch C, Richardson MK, Jiménez R, de Bakker MAG, Sánchez-Villagra MR (2012) Transcriptional heterochrony in talpid mole autopods. Evo-Devo (BMC) 3:16

Bininda-Emonds ORP, Jeffery JE, Sánchez-Villagra MR, Hanken J, Colbert M, Pieau C, Selwood L, Cate C t, Raynaud A, Osabutey CK, Richardson MK (2007) Forelimb-hind limb developmental timing across tetrapods. BMC Evol. Biol $7: 182$

Black KH, Archer M, Hand SJ, Godthelp H (2012) The rise of Australian marsupials: a synopsis of biostratigraphic, phylogenetic, palaeoecologic and palaeobiogeographic understanding. In: Talent JA (ed) Earth and Life: Global Biodiversity, Extinction Intervals and Biogeographic Perturbations Through Time. Springer, Dordrecht, pp 983-1078

Bloch JI, Rose KD, Gingerich PD (1998) New species of Batodonoides (Lipotyphla, Geolabididae) from the early Eocene of Wyoming: smallest known mammal? J Mammal 79:804-827

Burghardt GM (2005) The Genesis of Animal Play: Testing the Limits. Wiley, Chichester

Cannon B, Nedergaard J (2004) Brown adipose tissue: function and physiological significance. Physiol Rev 84:277-359

Case JA, Goin FJ, Woodburne MO (2004) "South American" marsupials from the Late Cretaceous of North America and the origin of marsupial cohorts. J Mammal Evol 11:223-255

Ceballos G, Ehrlich PR (2009) Discoveries of new mammal species and their implications for conservation and ecosystem services. Proc Natl Acad Sci USA 106:3841-3846

Chornogubsky L, Goin FJ, Reguero M (2009) A reassessment of Antarctic polydolopid marsupials (middle Eocene, La Meseta Formation). Antarctic Sci 21:285-297

Cifelli RL, Muizon C de (1998) Tooth eruption and replacement pattern in early marsupials. Compt Rend de l'Acad Sci Série II Sci Terr Planèt 326:215-220

Coetzee JM (1986) Foe. Penguin Books, UK

Cooper J, Steppan SJ (2010) Developmental constraint on the evolution of marsupial forelimb morphology. Austral J Zool 58:1-15
Dawson TJ, Mifsud B, Raad MC, Webster KN (2004) Aerobic characteristics of red kangaroo skeletal muscles: is a high aerobic capacity matched by muscle mitochondrial and capillary morphology as in placental mammals? J Exp Biol 207:2811-2821

Dickman C (2007) A Fragile Balance. The Extraordinary Story of Australian Marsupials. University of Chicago Press, Chicago

Dos Reis M, Inoue J, Hasegawa M, Asher RJ, Donoghue PCJ, Yang Z (2012) Phylogenomic datasets provide both precision and accuracy in estimating the timescale of placental mammal phylogeny. Proc Roy Soc B 279:3491-3500

Forasiepi AM, Carlini AA (2010) A new thylacosmilid (Mammalia, Metatheria, Sparassodonta) from the Miocene of Patagonia, Argentina. Zootaxa 2552:55-68

Formoso AE, Sauthier Udrizar DE, Teta P, Pardiñas UFJ (2011) Densesampling reveals a complex distributional pattern between the southernmost marsupials Lestodelphys and Thylamys in Patagonia, Argentina. Mammalia 75:371-379

Fortelius M, Kappelman J (1993) The largest land mammal ever imagined. Zool J Linn Soc 108:85-101

Fox RC, Naylor BG (2006) Stagodontid marsupials from the Late Cretaceous of Canada and their systematic and functional implications. Acta Palaeontol Pol 51:13-36

Frankenberg F, Dopheide B, Shaw G, Renfree MB (2011) A novel MSMB-related microprotein in the postovulatory egg coats of marsupials. BMC Evol Biol 11:373

Fröbisch NB (2008) Ossification patterns in the tetrapod limb - conservation and divergence from morphogenetic events. Biol Rev 83:571-600

Gavrilets S, Losos JB (2009) Adaptive radiation: contrasting theory with data. Science 323:732-737

Geiser F (1994) Hibernation and daily torpor in marsupials: a review. Austral J Zool 42:1-16

Gemmel RT, Veitch C, Nelson J (2002) Birth in marsupials. Comp Bioch Physiol 131:621-630

Godthelp H, Archer M, Cifelli RL, Hand SJ, Gilkeson CF (1992) Earliest known Australian Tertiary mammal fauna. Nature 356:514-516

Goin FJ, Abello MA, Chornogubsky L (2010) Middle Tertiary marsupials from central Patagonia (early Oligocene of Gran Barranca): Understanding South America's Grande Coupure. In: Madden RH, AA Carlini, MG Vucetich, RF Kay (eds) The Paleontology of Gran Barranca: Evolution and Environmental Change through the Middle Cenozoic of Patagonia. Cambridge University Press, Cambridge, pp 36-47

Goin FJ, Case JA, Woodburne MO, Vizcaíno SF, Reguero MA (1999) New discoveries of "opposum-like" marsupials from Antarctica (Seymour Island, medial Eocene). J Mammal Evol 6:335-365

Goin FJ, Zimicz AN, Forasiepi AM, Chornogubsky L, Abello MA (2012) The rise and fall of South American metatherians: contexts, adaptations, radiations, and extinctions. In: Rosenberger AL, MF Tejedor (eds) Origins and Evolution of Cenozoic South American Mammals. Springer Verlag, Berlin

Gordon G, Hulbert AJ (1989) Fauna of Australia: Mammalia. Australian Government Publishing Service, Canberra

Goswami A (2012) A dating success story: genomes and fossils converge on placental mammal origins. EvoDevo 3:18

Goswami A, Milne N, Wroe S (2011) Biting through constraints: cranial morphology, disparity, and convergence across living and fossil carnivorous mammals. Proc Roy Soc B 278:18311839

Goswami A, Polly PD, Mock O, Sánchez-Villagra MR (2012) Shape, variance and integration during craniogenesis: contrasting marsupial and placental mammals. J Evol Biol 25:862-872

Goswami A, Weisbecker V, Sánchez-Villagra MR (2009) Developmental modularity and the marsupial-placental dichotomy. J Exp Zool B Mol Dev Evol 312B:186-195

Gould SJ (1977) Ontogeny and Phylogeny. Belknap Press, Cambridge 
Gould SJ (1980) The Panda's Thumb. W.W. Norton and Company, New York

Hamrick MW (1999) Development of epiphyseal structure and function in Didelphis virginiana (Marsupiala, Didelphidae). J Morphol 239:283-296

Hand SJ, Novacek MJ, Godthelp H, Archer M (1994) First Eocene bat from Australia. J Vertebr Paleontol 14:375-81

Hand SJ, Weisbecker V, Beck RM, Archer M, Godthelp H, Tennyson AJ, Worthy TH (2009) Bats that walk: a new evolutionary hypothesis for the terrestrial behaviour of New Zealand's endemic mystacinids. BMC Evol Biol 9:169

Hautier L, Weisbecker V, Sánchez-Villagra MR, Goswami A, Asher RJ (2010) Skeletal development in sloths and the evolution of mammalian vertebral patterning. Proc Natl Acad Sci USA 107:1890318908

Hayward JS, Lisson PA (1992) Evolution of brown fat: its absence in marsupials and monotremes. Can J Zool 70:171-179

Holloway JC, Geiser F (2001) Seasonal changes in the thermoenergetics of the marsupial sugar glider, Petaurus breviceps. J Comp Physiol B 171:643-650

Hooker JJ, Sánchez-Villagra MR, Goin FJ, Simons EL, Attia Y, Seiffert ER (2008) The origin of Afro-Arabian 'didelphimorph' marsupials. Palaeontology 51:635-648

Hope PJ, Pyle D, Daniels CB, Chapman I, Horowitz M, Morley JE, Trayhurn P, Kumaratilake J, Wittert G (1997) Identification of brown fat and mechanisms for energy balance in the marsupial, Sminthopsis crassicaudata. Am J Physiol. 273(1 Pt 2):R161-7

Horovitz I, Martin T, Bloch J, Ladevèze S, Kurz C, Sánchez-Villagra MR (2009) Cranial anatomy of the earliest marsupials and the origin of opossums. Plos One 4(12):e8278

Hughes RL, Hall LS (1988) Structural adaptations of the newborn marsupial. In: Tyndale-Biscoe CH, PA Janssens (eds) The Developing Marsupial. Springer Verlag, Berlin, pp 8-27

Isler K, CP van Schaik (2009) The expensive brain: a framework for explaining evolutionary changes in brain size. J Hum Evol 57:392-400

Jastroch M, Withers KW, Taudien S, Frappell PB, Helwig M, Fromme T, Hirschberg V, Heldmaier G, McAllan BM, Firth BT, Burmester T, Platzer M, Klingenspor M (2008) Marsupial uncoupling protein 1 sheds light on the evolution of mammalian nonshivering thermogenesis. Physiol Genom 32:161-169

Jones ME (2003) Convergence in ecomorphology and guild structure among marsupial and placental carnivores. In: Jones ME, C Dickman, M Archer (eds) Predators with Pouches: The Biology of Carnivorous Marsupials. CSIRO Publishing, Collingwood, Victoria, pp 269-285

Kay RF, MacFadden BJ, Madden RH, Sandeman H, Anaya F (1998) Revised age of the Salla beds, Bolivia, and its bearing on the age of the Deseadan South American Land Mammal 'Age'. J Vertebr Paleontol 18:189-199

Kelly EM, Sears KE (2011a) Limb specialization in living marsupial and eutherian mammals: an investigation of constraints on mammalian limb evolution. J Mammal 92:1038-1049

Kelly EM, Sears KE (2011b) Reduced integration in marsupial limbs and the implications for mammalian evolution. Biol J Linn Soc 102:22-36

Keyte AL, Smith KK (2010) Developmental origins of precocial forelimbs in marsupial neonates. Development 137:4283-4294

Keyte AL, Smith KK (2012) Heterochrony in somitogenesis rate in a model marsupial, Monodelphis domestica. Evol Devel 14:93-103

Kirsch JAW (1977) The six-percent solution: second thoughts on the adaptedness of the Marsupialia. Am Sci 65:276-288

Koenigswald WV, Goin FJ (2000) Enamel differentiation in South American marsupials and a comparison of placental and marsupial enamel. Paleontographica A255:129-168
Koyabu D, Endo H, Mitgutsch C, Suwa G, Catania KC, Zollikofer CPE, Oda S, Koyasu K, Ando M, Sánchez-Villagra MR (2011) Heterochrony and developmental modularity of cranial osteogenesis in lipotyphlan mammals. Evo Devo 2:21

Lillegraven JA (1975) Biological considerations of the marsupialplacental dichotomy. Evolution 29:707-722

Lillegraven JA (2003) Polarities in mammalian evolution seen through homology of the inner cell mass. J Mammal Evol 10:277-333

Lillegraven JA, Thompson SD, McNab BK, Patton JL (1987) The origin of eutherian mammals. Biol J Linn Soc 32:281336

Liow LH, Fortelius M, Lintulaakso K, Mannila H, Stenseth NC (2009) Lower extinction risk in sleep-or-hide mammals. Am Nat 178:264-272

Losos JB (2010) Adaptive radiation, ecological opportunity, and evolutionary determinism. Am Nat 175:623-639

Luckett WP (1993) An ontogenetic assessment of dental homologies in therian mammals. In: Szalay FS, Novacek MJ, McKenna MC (eds) Mammalian Phylogeny: Mesozoic. Differentiation, Multituberculates, Monotremes, Early Therians and Marsupials. Springer, New York, pp 182-204

Luo Z-X (2007) Transformation and diversification in the early mammalian evolution. Nature 450:1011-1019

Luo Z-X, Ji Q, Wible JR, Yuan C.-X (2003) An Early Cretaceous tribosphenic mammal and metatherian evolution. Science 302:1934-1940

Luo Z-X, Yuan C-X, Meng Q-J, Ji Q (2011) A Jurassic eutherian mammal and the divergence of marsupials and placentals. Nature 476:442-445

Lynch VJ, Tanzer A, Wang Y, Leung FC, Gellersen B, Wagner GP (2008) Adaptive changes in the transcription factor HoxA-11 are essential for the evolution of pregnancy in mammals. Proc Natl Acad Sci USA 105:14928-14933

Maridet O, Costeur L (2010) Diversity trends in Neogene European ungulates and rodents: large scale comparisons and perspectives. Naturwissenschaften 97:161-172

Marshall LG (2004) The terror birds of South America. Sci Am, Spec Ed 14: 82-89

Martin GM, De Santis LJM, Moreira GJ (2008) Southernmost record for a living marsupial. Mammalia 72:131-134

McNab BK (2005) Uniformity in the basal metabolic rate of marsupials: its causes and consequences. Rev Chil Hist Nat 78:183198

McNab BK (2008) An analysis of the factors that influence the level and scaling of mammalian BMR. Comp Biochem Physiol A 151:5-28

Meredith RW, Janečka JE, Gatesy J, Ryder OA, Fisher CA, Teeling EC, Goodbla A, Eizirik E, Simão TL, Stadler T, Rabosky DL, Honeycutt RL, Flynn JJ, Ingram CM, Steiner C, Williams TL, Robinson TJ, Burk-Herrick A, Westerman M, Ayoub NA, Springer MS, Murphy WJ (2011) Impacts of the Cretaceous terrestrial revolution and $\mathrm{K} / \mathrm{Pg}$ extinction on mammal diversification. Science 334:521-524

Meredith RW, Westerman M, Case JA, Springer MS (2008) A phylogeny and timescale for marsupial evolution based on sequences for five nuclear genes. J Mammal Evol 15:1-36

Meslin C, Mugnier S, Callebaut I, Laurin M, Pascal G, Poupon A, Goudet G, Monget P (2012) Evolution of genes involved in gamete interaction: evidence for positive selection, duplications and losses in vertebrates. PLoS One 7(9): e44548.

Mitgutsch C, Olsson L, Haas A (2009) Early embryogenesis in discoglossoid frogs: a study of heterochrony at different taxonomic levels. J Zool Syst Evol Res 47:248-257

Mitgutsch C, Richardson MK, Jiménez R, Martín JE, Kondrashov P, de Bakker MAG, Sánchez-Villagra MR (2012) Circumventing the 
pentadactyly 'constraint' - autopodial recruitment of pre-axial structures in true moles. Biol Lett 8:74-77

Moczek AP, Sultan S, Foster S, Ledon-Rettig C, Dworkin I, Nijhout HF, Abouheif E, Pfennig D (2011) The role of developmental plasticity in evolutionary innovation. Proc Roy Soc B 278:27052713

Muizon C de (1991) La fauna de mamíferos de Tiupampa (Paleoceno Inferior, Formación Santa Lucía) Bolivia. In: Suarez-Soruco R (ed) Fósiles y Facies de Bolivia, Volúmen I Vertebrados, Revista Técnica de Yacimientos Petrolíferos Fiscales de Bolivia 12:575-624

Muizon C de, Céspedes R (2012) The beginning of the age of therian mammals in South America: Tiupampa, a transition between Northern and Southern worlds in the basal Paleocene. In: Rosenberger AL, MF Tejedor (eds) Origins and Evolution of Cenozoic South American Mammals. Springer Verlag, Berlin

Nilsson MA, Arnason U, Spencer PBS, Janke A (2004) Marsupial relationships and a timeline for marsupial radiation in South Gondwana. Gene 340:189-196

Novacek MJ (1992) Mammal phylogeny: shaking the tree. Nature $356: 121-125$

Oliveira EV, Goin FJ (2006) Marsupials do inicio do Terciário da Bacia de Itaboraí: origen, irradiação, e história biogeográfica. In: Caceres NC, Monteiro Filho ELA (eds) Marsupiais do Brasil. Biologia, Ecologia e Evoluçao, Ed. UFMS, Campo Grande, pp 299-320

Parent CE, Crespi BJ (2006) Sequential colonization and rapid diversification of Galápagos' endemic land snail genus Bulimulus (Gastropoda, Stylommatophora). Evolution 60:2311-2328

Pascual R, Archer M, Ortiz Jaureguizar E, Prado JL, Godthelp H, Hand SJ (1992) First discovery of monotremes in South America. Nature 356:704-706

Patterson B, Pascual R (1972) The fossil mammal fauna of South America. In: Keast AN, Erk FC, Glass B (eds) Evolution, Mammals and Southern Continents. State University of New York Press, New York, pp 274-309

Phillips MJ, Bennett TH, Lee MSY (2009) Molecules, morphology, and ecology indicate a recent, amphibious ancestry for echidnas. Proc Natl Acad Sci USA 106: 17089-17094

Pigot AL, Phillimore AB, Owens IPF, Orme CDL (2010) The shape and temporal dynamics of phylogenetic trees arising from geographic speciation. Syst Biol 59:660-673

Pough FH, Janis CM, Heiser JB (2008) Vertebrate Life. 8th edition. Benjamin Cummings, New Jersey

Prevosti FJ, Forasiepi AM, Zimicz NA (2011) The evolution of the Cenozoic terrestrial mammalian predator guild in South America: competition or replacement? J Mammal Evol. doi:10.1007/ s:10914-011-9175-9

Prevosti FJ, Turazzini GF, Ercoli MD, Hingst-Zaher E (2012) Mandible shape in marsupial and placental carnivorous mammals: a morphological comparative study using geometric morphometrics. Zool J Linn Soc 164:836-855

Rabosky DL, Alfaro ME (2010) Evolutionary bangs and whimpers: methodological advances and conceptual frameworks for studying exceptional diversification. Syst Biol 59:615-618

Renfree MB (1993) Ontogeny, genetic control, and phylogeny of female reproduction in monotreme and therian mammals. In: Szalay FS, Novacek MJ, McKenna MC (eds) Mammal Phylogeny: Mesozoic Differentiation, Multituberculates, Monotremes, Early Therians, and Marsupials. Springer-Verlag, New York, pp 4-20

Richardson MK (1999) Vertebrate evolution: the developmental origins of adult variation. BioEssays 21:604-613

Richardson MK, Gobes S, Leeuwen A van, Poelman A, Pieau C, Sánchez-Villagra MR (2009) Heterochrony in limb evolution: developmental mechanisms and natural selection. J Exp Zool B Mol Dev Evol 312B:639-664
Rose KD (2006) The Beginning of the Age of Mammals. Johns Hopkins University Press, Baltimore

Rougier GW, Apesteguía S, Gaetano L (2011) Highly specialized mammalian skulls from the Late Cretaceous of South America. Nature 479:98-102

Rougier GW, Wible JR, Novacek MJ (1998) New specimens of Deltatheridium, implications for the early history of marsupials. Nature 396:459-463

Rougier GW, Wible JR, Beck RMD, Apesteguía S (2012) The Miocene mammal Necrolestes demonstrates the survival of a Mesozoic non-therian lineage into the late Cenozoic of South America. Proc Natl Acad Sci USA 109:20053-20058

Sánchez-Villagra MR, Goswami A, Weisbecker V, Mock O, Kuratani S (2008) Conserved relative timing of cranial ossification patterns in early mammalian evolution. Evol Devel 10:519-530

Sánchez-Villagra MR, Narita Y, Kuratani (2007) Thoracolumbar vertebral number: the first skeletal synapomorphy for afrotherian mammals. Syst Biodiv 5:1-7

Schulte P, Alegret L, Arenillas I, Arz JA, Barton PJ, Bown PR, Bralower TJ, Christeson GL, Claeys P, Cockell CS, Collins GS, Deutsch A, Goldin TJ, Goto K, Grajales-Nishimura JM, Grieve RA, Gulick SP, Johnson KR, Kiessling W, Koeberl C, Kring DA, MacLeod KG, Matsui T, Melosh J, Montanari A, Morgan JV, Neal CR, Nichols DJ, Norris RD, Pierazzo E, Ravizza G, Rebolledo-Vieyra M, Reimold WU, Robin E, Salge T, Speijer RP, Sweet AR, Urrutia-Fucugauchi J, Vajda V, Whalen MT, Willumsen PS (2010) The Chicxulub asteroid impact and mass extinction at the Cretaceous-Paleogene boundary. Science 27:1214-1218

Sears KE (2004) Constraints on the morphological evolution of marsupial shoulder girdles. Evolution 58:2353-2370

Sears KE (2009) Differences in the timing of prechrondrogenic limb development in mammals: the marsupial-placental dichotomy resolved. Evolution 63:2193-2200

Sears KE, Behringer RR, Rasweiler JJ, Niswander LA (2006) The development of bat flight: morphologic and molecular evolution of bat forelimb digit. Proc Natl Acad Sci USA 103: $6581-6586$

Simpson GG (1980) Splendid Isolation. The Curious History of South American Mammals. Yale University Press, New Haven

Smith KK (2001a) Heterochrony revisited: the evolution of developmental sequences. Biol J Linn Soc 73:169-186

Smith KK (2001b) Early development of the neural plate, neural crest and facial region of marsupials. J Anat 199:121-131

Springer MS, Stanhope MJ, Madsen O, de Jong WW (2004) Molecules consolidate the placental mammal tree. Trends Ecol Evol 19:430438

Sumiyama K, Miyake T, Grimwood J, Stuart A, Dickson M, Schmutz J Ruddle F, Myers R, Amemiya CT (2012) Theria-specific homeodomain and cis-regulatory element evolution of the Dlx3-4 bigene cluster in 12 different mammalian species. J Exp Zool B Mol Dev Evol 318:639-50

Tejedor MF, Goin FJ, Gelfo JN, López G, Bond M, Carlini AA, Scillato-Yané GJ, Woodburne MO, Chornogubsky L, Aragón E, Reguero MA, Czaplewski NJ, Vincon S, Martin GM, Ciancio MR (2009) New early Eocene mammalian fauna from western Patagonia, Argentina. Am Mus Novitates 3638:1-42

Tyndale-Biscoe H (2005) Life of Marsupials. CSIRO Publishing, Collingwood

Ungar PS (2010) Mammal Teeth. John Hopkins University Press, Baltimore

Vaglia JL, Smith KK (2003) Early differentiation and migration of cranial neural crest in the opossum, Monodelphis domestica. Evol Devel 5:121-135

van Nievelt AFH, Smith KK (2005) To replace or not to replace: the significance of reduced tooth replacement in marsupial and placental mammals. Paleobiology 31:324-346 
Voss RS, Jansa SA (2009) Phylogenetic relationships and classification of didelphid marsupials, an extant radiation of New World metatherian mammals. Bull Am Mus Natl Hist 322:1-177

Vullo R, Gheerbrant E, Muizon C de, Néraudeau D (2009) The oldest modern therian mammal from Europe and its bearing on stem marsupial paleobiogeography. Proc Natl Acad Sci USA 106: 19910-19915

Wagner A (2011) The Origins of Evolutionary Innovations. Oxford University Press, Oxford

Weisbecker V (2011) Monotreme ossification sequences and the riddle of mammalian skeletal development. Evolution 65: 1323-1335

Weisbecker V, Goswami A (2010) Brain size, life history, and metabolism at the marsupial/placental dichotomy. Proc Natl Acad Sci USA 107:16216-16221

Weisbecker V, Goswami A, Wroe S, Sánchez-Villagra MR (2008) Ossification heterochrony in the mammalian postcranial skeleton and the marsupial-placental dichotomy. Evolution 62:2027-2041

Werdelin L (1987) Jaw geometry and molar morphology in marsupial carnivores: analysis of a constraint and its macroevolutionary consequences. Paleobiology 13:342-350

Werdelin L (1988) Circumventing a constraint - the case of Thylacoleo (Marsupialia, Thylacoleonidae). Austral J Zool 36:565-571

Wiens JJ (2011) The causes of species richness patterns across space, time, and clades and the role of "ecological limits". Quart Rev Biol 86:75-96

Wilson GP (2005) Mammalian faunal dynamics during the last 1.8 million years of the Cretaceous in Garfield County, Montana. J Mammal Evol 12:53-76

Wilson DE, Reeder DM (2005) Mammal Species of the World. Third Edition. Johns Hopkins University Press, Baltimore

Wilson GP, Dechesne M, Anderson I (2010) New latest Cretaceous mammals from northeastern Colorado with biochronologic and biogeographic implications. J Vertebr Paleontol 30:499-520.

Wilson GP, Evans AR, Corfe IJ, Smits PD, Fortelius M, Jernvall J (2012) Adaptive radiation of multituberculate mammals before the extinction of dinosaurs. Nature 483:457-460
Wilson LAB, Sánchez-Villagra MR (2010) Diversity trends and their ontogenetic basis: an exploration of allometric disparity in rodents. Proc Roy Soc B 277:1227-1234

Woodburne M (2010) The Great American Biotic Interchange: dispersals, tectonics, climate, sea level, and holding pens. J Mammal Evol 17:245-264

Woodburne MO, Case JA (1996) Dispersal, vicariance, and the Late Cretaceous to early Tertiary land mammal biogeography from South America to Australia. J Mammal Evol 3:121-161

Woodburne MO, Zinsmeister WJ (1982) Fossil land mammal from Antarctica. Science 218:284-285

Wroe S, Archer M (1995) Extraordinary diphyodonty-related change in dental function for a tooth of the extinct marsupial Ekaltadeta ima (Propleopinae, Hypsiprymnodontidae). Arch Oral Biol 40:597-603

Wroe S, Argot C, Dickman C (2004a) On the rarity of big fierce carnivores and primacy of isolation and area: tracking large mammalian carnivore diversity on two isolated continents. Proc Roy Soc B 271:1203-1211

Wroe S, Brammall J, Cooke BN (1998) The skull of Ekaltadeta ima (Marsupialia: Hypsiprymnodontidae?): an analysis of some cranial features among marsupials and a re-investigation of propleopine phylogeny, with notes on the inference of carnivory in mammals. J Paleontol 72:738-751

Wroe S, Crowther M, Dortch J, Chong J (2004b) The size of the largest marsupial and why it matters. Proc Roy Soc B (Suppl) 271:34-S36

Wroe S, Milne N (2007) Convergence and remarkably consistent constraint in the evolution of carnivore skull shape. Evolution 61:1251-1260

Wroe S, Myers T, Seebacher F, Kear B, Gillespie A, Crowther M, Salisbury S (2003) An alternative method for predicting body-mass: the case of the marsupial lion, Thylacoleo carnifex. Paleobiology 29:404-412

Zachos J, Pagani M, Sloan L, Thomas E, Billups K (2001) Trends, rhythms, and aberrations in global climate $65 \mathrm{Ma}$ to present. Science 292:686-693

Zack S, Penkrot TA, Bloch JI, Rose KD (2005) Affinities of 'hyopsodontids' to elephant shrews and a Holarctic origin of Afrotheria. Nature 434:497-501 